\title{
Effect of Growing Location on Internally- Seedborne Fungi, Seed Germination, and Field Emergence of Pigeon Pea in Puerto Rico $^{1}$
}

\author{
M. A. Ellis, E. H. Paschal, E. J. Ravalo, and Eileen Rosario ${ }^{2}$
}

\begin{abstract}
Fungi representing 10 genera were isolated from internal tissues of pigeon pea seeds of four cultivars grown at Isabela, P. R. Seed quality of all cultivars tested from Isabela was low (low percentage seed germination and high incidence of seedborne fungi). The occurrence of fungi from seeds of the cultivar 2BBushy, which had poor physical appearance (wrinkled seedcoat and discolored) was higher, and germination was lower, than for seeds of good physical appearance (uniform shape and color).

Seed of cultivar 2B-Bushy produced at Fortuna, P.R. had less internallyseedborne fungi and greater germination in vitro and emergence in the field than seeds produced at Isabela. The occurrence of total internally-seedborne fungi, Phomopsis sp., Lasiodiplodia theobromae, Fusarium semitectum, and Alternaria tenuissima was negatively correlated with emergence in the field. The occurrence of Aspergillus sp. was not negatively correlated with field emergence.
\end{abstract}

\section{INTRODUCTION}

Pigeon pea [Cajanus cajan (L.) Millsp.] is a tropically-adapted bush legume which provides a rich source of protein (6). In 1975-1976, the pigeon pea industry contributed $\$ 3.3$ million to the economy of Puerto Rico (2).

In 1975-1976, one of the limiting factors of pigeon pea production in Puerto Rico was poor seed germination and emergence in the field. The average field emergence of some 4-hectare fields was as low as 28 to $45 \%$. Ellis et al. (3) reported that seed used for planting these fields had an in vitro germination and incidence of internally-seedborne fungi of 60 and $75 \%$, respectively. This suggests that internally-seedborne fungi may play a major role in reducing the quality of pigeon pea seed in Puerto Rico.

Studies on soybean [Glycine $\max$ (L.) Merr.] $(5,7)$ and dry bean (Phaseolus vulgaris L.) (4) have shown that as the percentage of seeds infected by internally-seedborne fungi such as Phomopsis sp., Fusarium sp., and Alternaria sp. increases, the percentage seed germination and field emergence decreases.

In order to increase the production of pigeon pea in Puerto Rico, a source of high-quality disease-free seed must be made available to growers. Little has been published on the control of internally-seedborne

${ }^{1}$ Manuscript submitted to Editorial Board January 31, 1978.

${ }^{2}$ First and fourth authors, Department of Crop Protection; third author, Department of Agricultural engineering, University of Puerto Rico, Mayagüez; second author, Department of Agronomy, University of Illinois, Urbana. 
microorganisms of pigeon pea and their effect on seed germination and field emergence (1). This study reports on the effect of internally-seedborne fungi on seed quality of pigeon pea, and the effect of growing location in Puerto Rico on seed infection by fungi and seed quality of pigeon pea.

\section{MATERIALS AND METHODS}

In order to determine the seed quality of pigeon pea produced at Isabela, P.R., seeds of the cultivars, 2B-Bushy, Line 12, Line 69-68, and Kaki were obtained from cold storage at the Isabela Substation of the Agricultural Experiment Station. All seeds were produced in the 1975-1976 growing season at Isabela. Four hundred seeds of each cultivar were bioassayed for the presence of internally-seedborne fungi and germination in vitro. Seeds were surface disinfected by soaking in a $0.25 \%$ sodium hypochlorite solution for $2.5 \mathrm{~min}$, followed by $70 \%$ ethanol for 2 min, and finally rinsed in sterile, distilled water. Seeds were then transferred to potato dextrose agar (PDA) in culture plates (four seeds per plate) and incubated at $25^{\circ} \mathrm{C}$. After 7 days the occurrence of internallyseedborn fungi and percentage seed germination in vitro were recorded. All internally-seedborne fungi isolated from seed were identified at least to genus. Four replications of 100 seeds/cultivar which were not surface disinfected, were planted in a sandbench at the Isabela substation. Seedling emergence in sand was recorded after 10 days.

In a second experiment, 400 seeds of cultivar 2B-Bushy, which had good physical appearance (without wrinkles or cracks in the seedcoat and uniform in color), were selected. An additional 400 seeds, which had poor physical appearance (cracked or wrinkled seedcoats and discolored), were also selected. Both sets of seeds were surface disinfected and bioassayed as previously described.

In a third experiment, seed samples of cultivar 2B-Bushy were collected from seed production fields located at the Fortuna and Isabela substations. The following fields with their location, number of hectares planted, date of planting, and date of harvest, respectively, were sampled: 1) Isabela I, 2.43, August 13, 1976, January 4, 1977; 2) Isabela II, 3.24, August 16, 1976, January 11, 1977; 3) Fortuna I, 2.43, October 13, 1976, February 7, 1977; and 4) Fortuna II, 5.67, November 10, 1976, March 15, 1977. After harvest, four samples of 400 seeds were randomly collected from each field. Two hundred seeds from each sample were surface disinfected and bioassayed as previously described. The remaining 200 seeds from each sample were planted in the field at the Isabela substation. Emergence in the field was recorded after 15 days.

The following weather data were collected at the Isabela and Fortuna substations: maximum daily temperature, minimum daily temperature; rainfall and pan evaporation. 
Analysis of variance was calculated for percentage emergence in the field, germination on PDA, total internally-seedborne fungi and the recovery of fungi by genera for seeds from all fields sampled. Correlation coefficients were calculated between percentage emergence in the field, total internally-seedborne fungi, and occurrence of fungi by genera.

\section{RESULTS}

The following internally-seedborne fungi were isolated from the seeds bioassayed in this study: Phomopsis sp.; Lasiodiplodia theobromae; Fusarium semitectum; Alternaria tenuissima; Aspergillus sp.; Nigrospora sp., Penicillium sp.; Macrophomina sp.; Cladosporium sp. and Rhizopus sp. The seeds of all four cultivars which were obtained from cold storage at Isabela were of extremely poor quality. The percentage germination in vitro and emergence in sand did not exceed $60 \%$ for any cultivar tested (table 1). The percentage of seeds infected by fungi was not below $65 \%$ for all cultivars. Phomopsis sp. and L. theobromae were almost consistently isolated from dead (nongerminated) seeds. F. semitectum was frequently isolated from dead seeds and A. tenuissima was most frequently isolated from germinated seeds.

Seeds of the cultivar 2B-Bushy which had good physical appearance had a mean percentage germination in vitro of $93.7 \%$ and $64 \%$ of the seeds tested germinated and were free of internally-seedborne fungi (table 2). The mean percentage germination in vitro and seeds which germinated free of fungi for seeds of poor physical appearance were 34.3 and $6 \%$, respectively. The isolation of Phomopsis sp., $L$. theobromae, $F$. semitectum and $A$. tenuissima was more frequent from seeds of poor physical appearance than from seeds of good physical appearance (table 2).

The mean percentage field emergence and germination in vitro was significantly lower for seeds from both fields produced at Isabela than for seeds produced at Fortuna (table 3). Seed from the second planting at Isabela had significantly greater emergence in the field and germination in PDA than seeds from the first planting at Isabela. The occurrence of total internally-seedborne fungi, Phomopsis sp., L. theobromae, F. semitectum, and A. tenuissima was significantly higher for seeds from Isabela than for seeds from Fortuna. Seeds from the first planting at Isabela had significantly more of the above mentioned fungi than seeds from the second planting at Isabela (table 3 ). Seed from the first planting at Isabela had significantly less $A$. tenuissima than seed from the second planting at Isabela. Phomopsis sp. and L. theobromae were not isolated from seeds produced at Fortuna. Seeds from the first planting at Fortuna had significantly more Aspergillus sp. than seeds from the second planting (table 3). Aspergillus sp. was almost constantly isolated from germinated seeds. When field emergence was correlated with the incidence of total internally-seedborne fungi, Phomopsis sp., L. theobromae, F. sem- 
TABLE 1.-Percentage germination in vitro (PDA), emergence in sand, incidence of total internally-seedborne fungi, and occurrence of fungi by genera for seeds of four cultivars of pigeon pea produced at Isabela, P.R., 1975-1976

\begin{tabular}{|c|c|c|c|c|c|c|c|c|}
\hline \multirow{2}{*}{ Cultivar } & \multirow{2}{*}{$\begin{array}{l}\text { Germination in } \\
\text { vitro }\end{array}$} & \multirow{2}{*}{$\begin{array}{l}\text { Emergence in } \\
\text { sand }\end{array}$} & \multirow{2}{*}{ Total fungi } & \multicolumn{4}{|c|}{ Occurrence of fungi by genera } & \multirow{2}{*}{$\begin{array}{l}\text { Miscellaneous } \\
\text { fungi }\end{array}$} \\
\hline & & & & Phomopsis & Lasiodiplodia & Fusarium & Alternaria & \\
\hline 2B-Bushy & 36 & 38 & 85 & 22 & 21 & 17 & 20 & 5 \\
\hline Line 12 & 47 & 51 & 71 & 15 & 19 & 12 & 22 & 3 \\
\hline $69-68$ & 52 & 55 & 69 & 13 & 17 & 13 & 23 & 3 \\
\hline Kaki & 55 & 60 & 65 & 10 & 15 & 15 & 19 & 6 \\
\hline
\end{tabular}

${ }^{1}$ All figures based on 400 seeds/cultivar.

TABLE 2.-Percentage germination in vitro (PDA), seed which germinated and were free of fungi, incidence of total internally-seedborne fungi, and occurrence of fungi by genera for seeds of the cultivar 2B-Bushy of good and poor physical appearance

\begin{tabular}{|c|c|c|c|c|c|c|c|c|}
\hline \multirow{2}{*}{ Physical appearance } & \multirow{2}{*}{$\begin{array}{l}\text { Germinated free } \\
\text { of fungi }\end{array}$} & \multirow{2}{*}{$\begin{array}{c}\text { Germination in } \\
\text { vitro }\end{array}$} & \multirow{2}{*}{ Total fungi } & \multicolumn{4}{|c|}{ Occurrence of fungi by genera } & \multirow{2}{*}{$\begin{array}{l}\text { Miscellaneous } \\
\text { fungi }\end{array}$} \\
\hline & & & & Phomopsis & Lasiodiplodia & Fusarium & Alternaria & \\
\hline Good & 64 & 94 & 21 & 3 & 3 & 6 & 7 & 3 \\
\hline Poor & 6 & 34 & 93 & 23 & 27 & 17 & 21 & 4 \\
\hline
\end{tabular}

'All figures based on 400 seeds/seed classification.

TABLE 3.-Percentage emergence in the field, germination in vitro (PDA), incidence of total internally-seedborne fungi, and occurrence of fungi by genera from seeds of cultivar $2 B$-Bushy produced at Isabela and Fortuna, P. R., 1976-1977

\begin{tabular}{|c|c|c|c|c|c|c|c|c|c|}
\hline \multirow{2}{*}{$\begin{array}{l}\text { Location and date } \\
\text { planted }\end{array}$} & \multirow{2}{*}{$\begin{array}{l}\text { Field emer- } \\
\text { gence }\end{array}$} & \multirow{2}{*}{$\begin{array}{l}\text { Germination in } \\
\text { vitro }\end{array}$} & \multirow{2}{*}{ Total fungi } & \multicolumn{5}{|c|}{ Occurrence of fungi by genera } & \multirow{2}{*}{$\begin{array}{l}\text { Miscellaneous } \\
\text { fungi }\end{array}$} \\
\hline & & & & Phomopsis & Lasiodiplodia & Fusarium & Aspergillus & Alternaria & \\
\hline Isabela I & 41.0 & 49.7 & 73.8 & 10.8 & 18.8 & 19.0 & 0.2 & 11.7 & 12.1 \\
\hline Isabela II & 63.0 & 75.3 & 35.0 & .8 & 6.5 & 4.3 & 1.5 & 17.0 & 10.0 \\
\hline Fortuna I & 90.0 & 90.3 & 23.8 & 0 & 0 & 2.0 & 17.0 & 3.0 & 1.0 \\
\hline Fortuna II & 95.0 & 97.3 & 10.5 & 0 & 0 & 2.5 & 3.0 & 1.7 & 3.1 \\
\hline LSD .05 & 3.25 & 13.85 & 6.53 & 1.92 & 4.26 & 4.40 & 4.17 & 4.60 & 3.10 \\
\hline LSD .01 & 4.68 & 19.89 & 9.42 & 2.75 & 6.14 & 6.31 & 5.98 & 6.60 & 4.88 \\
\hline
\end{tabular}

\footnotetext{
'All figures based on four replications of 200 seeds/growing location and date of planting.
} 
itectum, A. tenuissima, and Aspergillus sp., the correlation coefficients were: $-.95 ;-.91 ;-.93 ;-.86 ;-.75$ and +.11 , respectively.

The mean daily temperatures at the Isabela and Fortuna substations for the time period in which the crops were in the field were about the same (table 4). However, rainfall was considerably less at the Fortuna substation, especially for the time period when the fields were maturing. Pan evaporation was higher at Fortuna than at Isabela.

\section{DISCUSSION}

The results of this study indicate that internally-seedborne fungi play a major role in reducing seed quality (percentage germination and field emergence) of pigeon pea in Puerto Rico. The occurrence of total inter-

TABLE 4.-Climatological data from the Fortuna and Isabela substations, 1976-1977

\begin{tabular}{|c|c|c|c|c|c|c|}
\hline \multirow{2}{*}{ Substation } & \multirow[b]{2}{*}{ Month } & \multicolumn{3}{|c|}{ Air temperature, ${ }^{\circ} \mathrm{C}$} & \multirow{2}{*}{ Rainfall } & \multirow{2}{*}{$\begin{array}{c}\text { Pan evapora } \\
\text { tion }\end{array}$} \\
\hline & & $\begin{array}{l}\text { Mean maxi- } \\
\text { mum }\end{array}$ & $\begin{array}{l}\text { Mean mini- } \\
\text { mum }\end{array}$ & Mean & & \\
\hline & & & & & $\mathrm{cm}$ & $\mathrm{cm}$ \\
\hline \multirow[t]{6}{*}{ Isabela } & September & 30.1 & 20.3 & 25.2 & 8.71 & I 3.23 \\
\hline & Octuoer & 28.7 & 20.8 & 24.6 & 6.50 & 11.81 \\
\hline & November & 29.3 & 18.5 & 23.9 & 9.47 & 13.54 \\
\hline & December & 28.1 & 16.6 & 22.4 & 12.70 & 10.59 \\
\hline & January & $27 . \overline{0}$ & 17.8 & 22.7 & 14.35 & 10.16 \\
\hline & Mean & 28.8 & 18.8 & 23.7 & 10.34 & 11.86 \\
\hline \multirow[t]{6}{*}{ Fortuna } & November & 31.2 & 21.2 & 26.2 & 1.24 & 13.31 \\
\hline & December & 30.1 & 19.8 & 24.9 & 2.03 & 13.99 \\
\hline & January & 29.5 & 18.6 & 24.1 & .68 & 14.10 \\
\hline & February & 30.0 & 19.7 & 24.8 & $.8 \mathrm{I}$ & 15.32 \\
\hline & March & 30.4 & 18.9 & 24.7 & 1.52 & 20.50 \\
\hline & Mean & 30.2 & 19.6 & 24.9 & 1.24 & 15.44 \\
\hline
\end{tabular}

nally-seedborne fungi, Phomopsis sp., L. theobromae, F. semitectum, and A. tenuissima was negatively correlated with emergence in the field. As seed infection by these fungi increased the percentage field emergence decreased. In addition, these fungi appeared to affect the physical appearance of the seed. Seeds which were wrinkled and discolored had a much higher percentage infection by fungi than seeds which had good physical appearance. Good physical appearance (uniformity in shape, color, and size) appears to be an important characteristic of high quality pigeon pea seed.

The seed quality of all cultivars produced at Isabela was extremely poor (low percentage germination and high percentage of seeds infected by fungi). This indicates that the quality of seed produced and used by farmers in the region of Isabela is poor. Seeds produced at Fortuna had excellent seed quality (high percentage germination and low percentage 
of seeds infected by fungi). The differences in the quality of seeds produced at Fortuna and Isabela are probably due to the differences in climate between the two regions. Humidity is probably the most important factor. Due to the low amount of rainfall and high amount of pan evaporation, the climatic conditions at Fortuna were much drier than at Isabela. Fungi usually require water for growth, reproduction, spore germination, and penetration of plant tissues.

The results of this study indicate that the selection and use of specific regions for production of pigeon pea seed in Puerto Rico could greatly increase seed quality. When seed production areas have been identified, they could be used to produce high quality seeds for other crops such as field bean, soybean, sorghum, and cowpea.

\section{RESUMEN}

Hongos de 10 géneros se aislaron del tejido interno de las semillas de cuatro cultivares del gandul (Cajanus cajan (L) Millsp.) sembrados en las subestaciones experimentales de Fortuna e Isabela, Puerto Rico. La calidad de las semillas de todos los cultivares sembrados en Isabela fue baja (un bajo porcentaje de germinación y una alta incidencia de hongos). La presencia de hongos en las semillas del cultivar 2B-Bushy, de pobre apariencia (testa arrugada y descolorida), era más abundante, y la germinación más pobre que en las semillas de buena apariencia (forma y color uniformes).

En el tejido interno de las semillas del cultivar 2B-Bushy cosechado en Fortuna habia menos hongos. Estas germinaron mucho mejor, tanto in vitro cumo en el campo, que las cosechadas en Isabela.

La presencia en el tejido interno de los hongos Phomopsis sp., Lasiodiplodia theobromae, Fusarium semitectum y Alternaria tenuissima estuvo correlacionada negativamente con la germinación en el campo, pero no así la de Aspergillus sp.

\section{LITERATURE CITED}

1. Barnes, R. F., 1973. A preliminary list of literature on pigeon pea [Cajanus (L.) Millsp.] -plant pathology. Dep. Biol. Sci., Univ. West Indies, Bull. No. 1, 23 pp.

2. Conjunto Tecnológico para la Producción de Gandules: Su Situación Económica y sus Perspectivas, 1977. Eta. Exp. Agric. Univ. P.R. Publ. 116.

3. Ellis, M. A., Foor, S. R., and Meléndez, P. L., 1976. Effect of internally seedborne fungi on germination of pigeon pea in Puerto Rico. Memorias de la Sociedad Puertorriqueña de Ciencias Agricolas 2: 8-9 (Abst.).

4. —- Gálvez, G. E., and Sinclair, J. B., 1976. Effect of folior applicaicions of systemic fungicides and late harvest on seed quality of dry bean (Phaseolus vulgaris). Plant Dis. Rep. 60: 1073-6.

5. - and Sinclair, J. B., 1976. Effect of benomyl sprays on internally-borne fungi, germination and emergence of late-harvested soybean seeds, Phytopathology 66: $680-2$.

6. Khan, T. N., and Rachie, K. O., 1972. Preliminary evaluation and utilization of pigeon pea germplasm in Uganda, East Afr. Agric. For. J. 38: 78-82.

7. Wilcox, J. R., Laviolette, F. A., and Athow, K. L., 1974. Deterioration of soybean seed quality associated with delayed harvest, Plant Dis. Kep. 58: 130-3. 